\title{
LEARNING MODEL FOR IMPROVING THE EFFECTIVENESS OF STUDENTS' LEARNING PERFORMANCE IN LESSONS
}

\author{
ROKSOLYANA SHVAY \\ Department of Pedagogy and Innovative Education \\ Institute of Law, Psychology and Innovative Education \\ Lviv Polytechnic National University \\ 12 Bandera Street, Lviv, Ukraine \\ E-mail: roksolyanash@yahoo.com \\ ORCID ID: orcid.org/ 0000-0003-3859-5196
}

\author{
HALINA RAROT \\ Faculty of Fundamentals of Technology \\ Lublin University of Technology \\ Nadbystrzycka 38 Lublin, Poland \\ E-mail: rarot@nowanet.pl \\ ORCID ID: orcid.org/ 0000-0002-9095-0872 \\ ANNA SHAYNER \\ Department of Foreign Languages \\ Institute of Humanities and Social Sciences \\ Lviv Polytechnic National University \\ 12 Bandera Street, Lviv, Ukraine \\ E-mail: ann.shayner@gmail.com \\ ORCID ID: orcid.org/0000-0002-0086-5579
}

\begin{abstract}
Aim. The objective of this study is to suggest and demonstrate the feasibility of a new learning model and to compare learning outcomes from both the traditional and the newly developed learning models.

Methods. The advantages of the developed model are demonstrated employing the statistical processing of the pedagogical experiment results with the use of Statistica. The experiment involves 786 students aged 13-14, who study in grades 7-8. The time parameters of the duration of individual elements of the lesson in the traditional learning model are consistent with the methodological literature (Horonovska \& Samsonova, 1985; Sadovyi, Vovkotrub, \& Tryfonova, 2013).

Results. A 'parallel' model has been developed by the example of teaching physics. The level of knowledge and skills of students who studied by the new 'parallel' model,
\end{abstract}


was higher than in the traditional one. The 'parallel' model of the lesson possesses the advantage of providing students with (almost 3 times) more active research activity during the lesson. The methodology of selecting generic content units (GCUs) from the subject content and their division into theoretical (TCUs) and experimental (ECUs) content units is elaborated.

Conclusions. The broad implication of the present research is that the developed 'parallel' model allows effective use of time for students' research work at physics lessons, and enables obtaining better learning outcomes, using individual and group forms of learning with the observance of individualization and differentiation learning principle. This model assists building pedagogical teaching technologies for different subjects.

Key words: 'parallel' learning model, content units, duration of the teaching and learning process

\section{INTRODUCTION}

$\mathrm{T}^{\mathrm{s}}$ he rapid development of the sciences is steadily increasing the disproportion between the level of student's psychic readiness to apprehend new information and the level of scientific knowledge acquisition. As far as the student-centered pedagogy is concerned, the relationship between the teacher and the student introduces changes not only on the mental plane but also in the sphere of emotional or mutual understanding within the moral domain. It is not necessary to teach the students the subject itself but to equip them with the knowledge on how to study the subject on their own. Alternatively, it means that the learning processes depend on many factors. It is vital to highlight that one of the significant factors is the student's individual apprehension of further information. It is recommended to teach students according to their abilities and potential (bmbwf. gv.at, 2007). Knowledge of mental processes, the person's information processing peculiarities, the perception and understanding of the material is necessary for the teacher to properly organize the educational activity and choose or build the appropriate pedagogical technology. Modern learning technologies develop different types of students' thinking. The ability to transit from abstract to concrete and vice versa indicates good integration of thinking components and enables to move away from stereotypical thinking (Szwaj, 2016).

It is crucial to organize the learning process in such a way as to implement individual approach towards each student, taking into account his or her characteristics, such as the rate of new informationapprehension, and therefore, the pace of work during the lesson. Individualization is referred to as the pace of learning. Learning is carried out at a different pace, but all students are able to achieve the specific learning goal (Bray \& McClaskey, n.d.). Anna Karpinska (2016) considers individualization to be the basic principle and value of the learning process, which requires the adaptation of content, methods, and means of learning to the learner's inclinations. Beata Karpeta-Peć (2017) states that not only personal abilities of the student should be taken into account in individualization, but also students' mutual activities. 
The teacher is obliged to investigate the achieved goal and the students' learning outcomes. Thus, the teacher and the student in the course of the learning process are connected by informative feedback, so the student is in charge and instructs the teacher on how to deliver the knowledge (Poveshchenko, 2014).

According to Vadym Rotenberg and Alexander Bondarenko (1989), theoretical knowledge, which is not gained from practical experience, is less usable, optional and easily lost. It is the knowledge gained independently as a result of the developed search strategy and not the knowledge that is obtained in the finished form that becomes significant to the student. This outlines a certain relationship in the teacher-student system. The teacher organizes students' activities concerning their knowledge acquisition by controlling and adjusting the learning process. The result is the difference in the acquisition of "in-trail" and "in-trail search" knowledge associated with reproductive and creative knowledge. These categories relate to the reproduction or creation of new structures of thought (Klus-Stańska, 2000). This is reflected in a change of priorities: the priority of learning is given over teaching, the process of thinking (how to think) over content (what to think). There is a change of emphasis, namely the transition from the issue what we want to apprehend to the aspect of how exactly we can apprehend (Schmidt, 2010a).

The teacher is to ensure that each student is taught at the appropriate level and in accordance with the requirements of the state standards (dreambox. com, 2020).

\section{RESEARCH METHOD AND PARTICIPANTS}

In order to test the effectiveness of the developed model, a pedagogical experiment was conducted among secondary school students. The experiments involved 786 students, who were divided into the control and the experimental groups. The study process was carried out traditionally in the control groups, whereas the experimental classes followed the requirements of the designed model using methodical material (Shvay \& Hirnyi, 2003a, 2003b, 2009, 2010; Shvay, 2002). The time parameters of completing the task by the students of the experimental group, obtained by observing the learning process, were recorded in the answer assessment sheets for task fulfillment (Shvay, 1999), and the time parameters of the individual elements of the traditional learning model lesson were consistent with the methodological literature (Horonovska \& Samsonova, 1985; Sadovyi, Vovkotrub \& Tryfonova, 2013). The assessment of the students' task fulfillment was based on a five-point grading scale. Statistical processing of the results of the experiment was carried out using Statistica. 


\section{THE RESULTS OF THE RESEARCH}

Through the experience of teaching physics at school, we would like to demonstrate that students with a different pace and various abilities and talents can be effectively taught by both selecting and designing teaching material as well as organizing the learning process.School physics experiments were used to fulfill this task. Methodically, it is interpreted as a combination of the time spent on the implementation of two main components of the learning process: teaching (delivering a new material by the teacher - teacher's activity) and learning (understanding and acquisition of the learning material by students the activity of students).

The basic structural elements of the physics course content of secondary education institutions in Ukraine were singled out. They built a new model of study that should allow combining practical actions of students with their mental activity (the developed methodology is not linked to specific educational programs). These structural elements were united into two large blocks:

1. Theoretical content units (TCUs) - the minimum content components - statements (formulations, descriptions, concepts, rules, etc.), everything that makes up the content of the teacher's teaching process (teacher's activity), extracted from the school's physics course.

2. Experimental Content Units (ECUs) - the selected tasks of the School Physics Experimental System (SPES) - separate groups of actions that, in content, coincide with the experiments, their parts or other types of practical actions that relate to the student's activity (learning).

ECUs and TCUs contain some amounts of information. TCUs assume a verbal form while ECUs a non-verbal form (support for visual images). This combination makes physics learning material more accessible in terms of apprehension, understanding and memorization.

The main criteria for the selection of the experimental contents were the minimum time for implementation; the minimum amount of special laboratory equipment needed; and the use of learning aids for conducting the experiment, familiar to students from their daily use and own life experiences.

Physics experiments are recommended to be simple and accessible to all students, and the content of the experiments should correlate with the theoretical teaching material in physics. The content of the experimentshould cover the full range of theoretical content of the curriculum. The number of suggested experiments is rather substantial and of various complexity to ensure the student's individual approach.

Experimental tasks are to guarantee the study of the fundamental theoretical provisions of the learning material, the selected material is to be diverse and interesting for students.

TCUs and ECUs were combined into GCUs - generalized content units, which make up the main content of physics educational course of a secondary education institution. The learning material is delivered in the form of GCUs, combined into a complete content structure of the learning manuals to orga- 
nize learning in accordance with the developed model (Shvay \& Hirnyy, 1999, 2000, 2003a, 2003b).

Each TCU corresponds to the activity of the teacher, and each ECU corresponds to the student's. The total time of all TCUs reflects the duration of the teaching process (teaching activity), while the total time of all ECUs amounts to the duration of the knowledge acquisition (learning activity), and the total time of all GCUs is the duration of the learning process.

In the traditional 'sequential' model of teaching physics, the content units are being consistently changed and are equal to the duration of the lesson, which is 45 minutes. Therefore, the 'sequential' learning model preserves the traditional distribution of teaching and learning activities within the time frame: namely, the teacher teaches and the students listen to him/her; the teacher demonstrates the experiment and the students observe the process; the teacher gives the task and the students perform it, etc.

A new 'parallel' model is tailored and customized. The teaching activity is integrated in time into the activity oflearning. Theoretically, in a 'parallel' scheme, the total study time of the lesson can be longer than the one restricted by students physical being in the classroom, that is, more than 45 minutes (see Fig. 1).

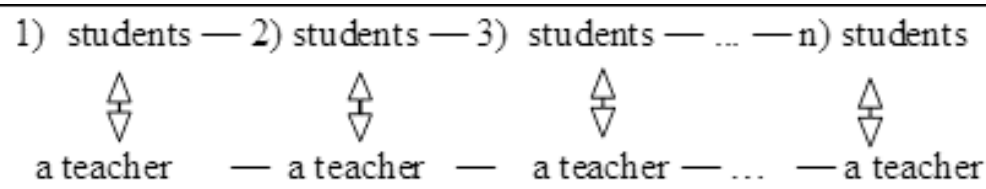

Figure 1. The learning scheme in the 'parallel' model

Source: Own research

The study of theoretical material does not necessarily imply separate time for its passive perception in the 'parallel' model.

In addition to the high learning intensity, the developed learning model provides an individual approach to each student. It enables the provision of a different pace of delivering new tasks (content units) for the students with the various individual pace of performance. There are three groups of studentsfast, moderate and slowregarding their information processing (Honcharuk, 1985).

The so-called 'fast' learners can perform more ECUs, and 'moderate' or 'slow' students in their turn perform less. The teacher works individually with the 'slow' students, whereas the 'fast' ones are provided with appropriate textbooks and learning aids, and can work independently. Performing the tasks of the SPE (School Physics Experiment) allows students to manage their activities (learning), that is, the speed of the ECUs delivery.

The use of the 'parallel' learning model makes it possible to train all students according to a single curriculum (both in volume and content) and at the same time implement an individual approach to each student. The multiplicity of ECUs, their performance by students, the students' answers to the questions in the course of conducting the experiments, the acquisition of certain practi- 
cal skills, these elements all provide the teacher with information about the perception and understanding of learning material by the students. The new knowledge is the upshot of the students' own discoveries, gained as a result of the experiments and practical activities. The obtained information is interpreted with the assistance of the teacher, compared with scientific physical laws, rules, etc., and acquired as a significant theoretical material.

Continuous performance of experiments at the lessons communicates emotions, disciplines students, and helps to focus attention on learning activities. Some experimental tasks are performed to accumulate facts, on the basis of which scientific generalizations are made, or to create problematic situations. A school physics experiment is a means of dosing information. The teacher delivers the learning material in small doses: didactic units. Students do a certain experiment and answer questions while the teacher attentively observes the process, assists verbally students having difficulty with performing the experiment or demonstrates some practical action.

The use of additional didactic material such as manuals and workbooks (Shvay \& Hirnyy, 2009) enables students to work independently, and the teacher is available to work individually with different categories of students. The tasks in the workbook convey various degrees of complexity. This allows students to work accordingly to their abilities and pace. It is not necessary for the so-called 'slow' students to perform all the experiments. Thus, they get extra time to think and understand theoretical material. There is a separate group of students who quickly and accurately complete the tasks and master the learning material. The teacher can work with them to deepen their acquired knowledge and improve their skills. The proposed new model introduces some changes in the learning process. Students are engaged in the active cognitive activity at the lessons. The teacher has a real opportunity to communicate with each student, identify those who need help or attention, and, therefore, provide such assistance. In the 'parallel' learning model, students acquire theoretical knowledge by means of their own discoveries, which is the path to creativity.

The developed learning model refers to the constructivist discourse that includes empirical concepts of constructive perception (Schmidt, 2010b).

Let's compare and evaluate the learning outcomes of two learning models: 'sequential' (traditional learning) and 'parallel' (a newly developed learning model) ones. The time and results of student's learning (assessment) are directly related to the evaluation of the learning effectiveness. Therefore, time and grades are selected as basic or indirect (through other variables) parameters serving to compare learning outcomes between the two learning models.

786 students from the 7 th forms, attending secondary education institutions, were enrolled in the experiment. The study process was carried out traditionally in the control groups whereas the experimental groups followed the requirements of the designed model. The time parameters of the duration of individual elements of the lesson in the traditional learning model was consistent with the methodological literature for teachers (Horonovska \& Samsonova, 1985; Sadovyi, Vovkotrub \& Tryfonova, 2013). All the teachers who participated in the 
experiment are highly qualified and experienced in working with students of the 7 th or 8 th forms. To calculate the time parameter of the duration of the TCUs and the ECUs according to the developed 'parallel' model, assessment answer sheets for the fulfillment of the tasks were used (Shvay, 1999), which had been placed in the 7th grade workbooks and graded by teachers (Shvay \& Hirnyy, 1999). The time of each task performance was determined as well.

The total learning time (the time of student's activity) was compared between the models of 'parallel' and traditional 'sequential' learning. Only a few students who followed the traditional learning model were engaged in a hands-on activity during the lesson. Hence, more students were engaged in a passive or neutral activity.

This aspect of the research suggests that there are only a few students $(2,3$, max. 8 students) who deal with a traditional model. They complete tasks (solve physics tasks, perform an experiment, answer the teacher's questions during the lesson, etc.). At the same time, other students in the class are only watching, listening and analyzing. The main part of the lesson, which lasts 35 minutes out of the total 45 minutes, is dedicated to the passive or neutral activity.

Table 1 shows two indicators: $t_{\text {min }}$ represents traditional learning, that is the time of one student's active performance at the lesson during the study of physics course in the 7th grade and belongs to the majority of students, $t_{\max }$ is the time of activity of one student, belonging to a few students who have been assessed at the lesson (2, 3, 7, max. 10 students), those engaged in active participation at the lesson.

Table 1.

Time needed to complete the tasks by a student in physics in the 7 th grade

\begin{tabular}{lll}
\hline Learning Models & $\mathbf{t}_{\min }, \mathbf{m i n}$ & $\mathbf{t}_{\max }, \mathbf{m i n}$ \\
\hline Sequential (traditional learning) & 495 & 1258 \\
\hline Parallel (new lesson model) & 1787 & \\
\hline
\end{tabular}

Source: Own research

As can be seen from Table 1, combining teaching (teacher) and student activity (students) time allows students much more time to be engaged in hands-on research. The time of active research activities of students in the 'parallel' model is 1.4-3.6 times longer than in the traditional, 'sequential' model (following the methodological recommendations).

The two models accomplish different tasks: the traditional model determines the optimal time spent on different teaching-learning activities, while the newly developed model maximizes learning activity in accordance with the new paradigm. Additionally, the 'sequential' model defines (for an average student) the time parameters of the activity, whereas the 'parallel' ignores this option.

An additional time parameter for evaluating learning models is the average active time indicator of one student at the lesson $\left(t_{a}\right)$. Time parameters are 
obtained from the assessment answer sheet to evaluate the 'parallel' model (Shvay, 1999). This parameter, according to the traditional teaching model, corresponds to the duration of the elements of the lesson as indicated by the methodological literature (Horonovska \& Samsonova, 1985; Sadovyi, Vovkotrub \& Tryfonova, 2013).

The following formula $t_{a}=\frac{\sum_{i=1}^{N} \tau_{i}}{N}$ has been used. Here, $\tau_{i}$ denotes the time of the i-th student's active cognitive activity for the task completion, $\mathrm{N}$ is the number of students in a class (an average class is supposed to consist of 30 students).

Two possible, extreme cases derived from the experience in teaching physics teaching using the 'sequential' model are considered:

a) each student performs one task which may include the student's answer to a teacher's problematic question, formulation of a certain physical law, explanation of a certain physical concept, exemplification of a physical phenomenon, its explanation, etc. Either the student performs an experiment or solves a problem, thus, few students $(2,3$, or max 8$)$ are actively engaged in a learning process;

b) one student performs several tasks (answers the teacher's questions, solves a problem, carries out an experiment). Therefore, the number of students engaged in active research during the lesson is reduced to 1-2.

More optimistic variant (a) is chosen for calculations. Hence, the highest values are used for the traditional model. Lessons with the same theoretical content are selected to compare the two learning models. The numbering of the lessons in Table 2 corresponds to the one in the workbook (Shvay \& Hirnyy, 1999).

Table 2 demonstrates that the 'parallel' model of learning possesses the advantage of providing students with (almost 3 times) more active research activity during the lesson. This indicator correlates with the previous one, namely the total time (see Table 1). We emphasize that an increase in time for the students' research work does not reduce the time for the teacher to explain the theoretical material. Higher efficiency of the 'parallel' learning process can be associated with the release of extra time for learning activities (the sum of ECUs) by combining teaching and learning time with the GCUs.

It is advisable to count the number of students' completed assignments within a fixed time frame (during the lesson). The separate tasks taken into consideration are: answering a teacher's question, solving a qualitative problem, solving a calculation problem, doing an experiment, carrying out a certain measurement, solving an experimental problem, performing an observation. 
Table 2.

Average active time $t$, $\min$

\begin{tabular}{|c|c|c|c|}
\hline \multirow[t]{2}{*}{$\mathbf{N}_{\text {topics }}$} & \multirow[t]{2}{*}{$\mathbf{N}_{\text {of the lesson }}$} & \multicolumn{2}{|c|}{ Learning model } \\
\hline & & sequential & parallel \\
\hline 1 & 1 & 0.16 & 7.50 \\
\hline \multirow[t]{4}{*}{2} & 1 & 10.50 & 20.37 \\
\hline & 2 & 0.47 & 15.37 \\
\hline & 3 & 0.47 & 28.57 \\
\hline & 4 & 12.70 & 20.45 \\
\hline \multirow[t]{11}{*}{3} & 1 & 5.70 & 9.48 \\
\hline & 3 & 15.30 & 33.40 \\
\hline & 4 & 30.00 & 34.93 \\
\hline & 6 & 5.50 & 8.37 \\
\hline & 7 & 0.70 & 14.07 \\
\hline & 9 & 0.43 & 36.93 \\
\hline & 11 & 6.60 & 22.62 \\
\hline & 15 & 15.10 & 20.37 \\
\hline & 16 & 0.30 & 27.03 \\
\hline & 18 & 14.00 & 12.73 \\
\hline & 20 & 5.20 & 27.12 \\
\hline \multirow[t]{8}{*}{4} & 1 & 5.40 & 21.45 \\
\hline & 2 & 0.70 & 11.17 \\
\hline & 3 & 20.00 & 13.30 \\
\hline & 4 & 5.30 & 19.22 \\
\hline & 6 & 15.30 & 34.68 \\
\hline & 8 & 25.20 & 19.50 \\
\hline & 9 & 0.16 & 24.70 \\
\hline & 10 & 0.46 & 20.97 \\
\hline \multirow[t]{5}{*}{5} & 1 & 0.16 & 34.05 \\
\hline & 2 & 7.30 & 20.20 \\
\hline & 4 & 0.33 & 17.75 \\
\hline & 5 & 0.30 & 28.47 \\
\hline & Tot & 74604.78 & \\
\hline
\end{tabular}

Source: Own research

This comparison indicates that, if, for example, 7th grade students answer 7 or 8 teacher's questions in physics in the traditional model, then students do 9 tasks in the 'parallel' model, where 6 tasks are exercises and math problems, and 3 are experimental problems. It should be emphasized again that only a few students are active if the traditional teaching is applied, whereas the developed model of the lesson is characterized by full involvement of the students in the active work at the appropriate pace.

A quantitative assessment of the tasks related to the SPE system, which develops students' abilities, is advisable. The standard program in physics 
defines a list of compulsory laboratory tasks and demonstration experiments. In-house experiments and observations have been further developed for the parallel model.

A demonstration experiment is transformed into students' experiments. Hence, an experiment demonstrated by a teacher in a traditional learning model is carried out by the students themselves in the new model. The calculation of the number of laboratory works and experiments done by the students in both tables shows the advantages of the 'parallel' learning model (see Table 3).

Table 3.

Number of laboratory works and experiments

\begin{tabular}{lcccc}
\hline $\begin{array}{c}\text { Model of } \\
\text { learning }\end{array}$ & \multicolumn{2}{c}{ Frontal } & $\begin{array}{c}\text { Demonstrated } \\
\text { experiment }\end{array}$ & $\begin{array}{c}\text { In-house } \\
\text { experiments and } \\
\text { observations }\end{array}$ \\
\cline { 2 - 4 } & laboratory works & experiments & & - \\
\hline sequential & 12 & - & 28 & 96 \\
\hline parallel & 12 & 70 & - & \\
\hline
\end{tabular}

Source: Own research

Students' activity is shown to be increased in the lesson in 'parallel' model because students spend more time doing research work.

In order to evaluate the effectiveness of the 'parallel' learning model, the nature of time parameters distribution for students' performance of all the tasks in Physics Workbook for the 7th grade was thoroughly studied (Shvay \& Hirnyy, 1999).

The nature of these parameters distribution was compared with the normal distribution based on $\chi^{2}$ - Pearson criterion. It was found that students' time spent on tasks was distributed according to normal law (set $\chi^{2} t .05$ ).

The next step was to study the correlation of time parameters between the students in the experimental group. To do this, each student's time parameter (the time spent carrying out the task) was analyzed for each lesson during the school year. A matrix of time-consuming correlations for each task performance among different students was calculated.

The analysis of coefficients correlation shows that a closer correlation is observed between students with the same level of learning outcomes. A correlation coefficient more than .7 is detected between the students with numbers (each student in the experiment was designated by a specific number) 8 and $5(\mathrm{r}=.747), 12$ and $3(\mathrm{r}=.711), 16$ and $12(\mathrm{r}=.774), 22$ and $19(\mathrm{r}=.744)$, 23 and $19(\mathrm{r}=.800), 23$ and $22(\mathrm{r}=.811), 19$ and $4(\mathrm{r}=.757)$. This reveals that the $8 \mathrm{th}, 5 \mathrm{th}, 3 \mathrm{rd}, 12 \mathrm{th}$ and 16 th students had excellent marks for control work (mostly 5), while the rest of those students obtained low marks (mostly 3). The assessment was based on a five-point grading scale. If we consider the indicators of students with a low correlation coefficient (less than 0.3), these were the students with different average scores for control work. For example, students with numbers 17 and $10(\mathrm{r}=.157), 17$ and $14(\mathrm{r}=.195), 11$ and $4(r=.259)$. 
The arithmetic mean of each student for the control work is used to compare the learning outcomes of the students working in one of the two models. The average scores of students in the experimental and control groups are distributed according to normal law (Table 4). The hypothesis of a random difference in grades between the experimental and control groups is chosen as null.

An alternative hypothesis is brought forward that the grades in the experimental group are higher than in the control group. The result of comparing the mean values in the experimental and control groups according to Student's $\mathrm{t}$-criterion and using Excel software is presented in Table 4 ( $t$ is set at .05).

Table 4.

Two-sample t-test with different variances

\begin{tabular}{lll} 
& $\begin{array}{l}\text { Control group } \\
\text { (CG) }\end{array}$ & $\begin{array}{l}\text { Experimental } \\
\text { group (EG) }\end{array}$ \\
Mean & $\mathbf{3 . 1 0 4 1 5 2}$ & 3.528165 \\
Dispersion & $\mathbf{0 . 2 4 3 4 7 5}$ & $\mathbf{0 . 4 3 4 0 9 3}$ \\
\hline Hypothetical average difference & 0 & \\
\hline $\mathrm{df}$ & 784 & \\
\hline $\mathrm{t}$-statistics & -3.69466 & \\
& & \\
\hline $\mathrm{P}(\mathrm{T}<=\mathrm{t})$ one-sided & 0.000245 & \\
\hline $\mathrm{t}$ - critical one-sided & 1.671553 & \\
\hline $\mathrm{P}(\mathrm{T}<=\mathrm{t})$ two-sided & 0.000489 & \\
\hline $\mathrm{t}$-critical bilateral & 2.001716 & \\
\hline
\end{tabular}

Source: Own research

$\leq$

Since $\mathrm{P}(\mathrm{T} t)=0.000245<0.01$, the null hypothesis is rejected and the alternative hypothesis is accepted: the level of knowledge and skills in the experimental group is higher than in the control group.

Thus, the obtained data confirm the hypothesis that the 'parallel' model results in the students' better learning outcomes. Firstly, students' level of knowledge and skills is directly related to the time spent on performing individual exercises and tasks at the lesson (in particular, experimental ones), and secondly, it is higher among the students in the experimental group.

The possibility of a link between the student's average grade and the time spent on completing the tasks during the lessons was explored. The correlation coefficients between the student's average grade for the control, laboratory works, and the average parameter of task completion time from the Workbook (Shvay \& Hirnyy, 1999) are shown in Table 5. 
Table 5.

Correlation coefficients between assessment and task performance time

\begin{tabular}{|l|l|l|l|l|l|l|l|l|l|}
\hline & T1 & T 2 & T3 & T 4 & T 5 & T 6 & T 7 & T 8 & T 9 \\
\hline G & -.10 & -.04 & -.09 & -.06 & -.02 & -.10 & -.13 & .03 & .07 \\
\hline LWG & -.14 & -.18 & -.24 & -.21 & -.12 & -.20 & -.22 & -.05 & .00 \\
\hline & T 10 & T 11 & T 12 & T 13 & T 14 & T 15 & T 16 & T 17 & T 18 \\
\hline G & -.09 & -.10 & -.01 & -.10 & -.07 & -.06 & .15 & .00 & .05 \\
\hline LWG & -.12 & -.20 & -.09 & -.18 & -.14 & -.12 & .07 & -.03 & -.03 \\
\hline & T 19 & T 20 & T 21 & T 22 & T 23 & T 24 & T 25 & T 26 & T 27 \\
\hline G & .03 & -.07 & -.15 & -.16 & -.13 & -.07 & -.09 & -.19 & -.05 \\
\hline LWG & -.07 & -.15 & -.27 & -.26 & -.26 & -.09 & -.13 & -.23 & -.18 \\
\hline & T 28 & T 29 & T 30 & T 31 & T 32 & ETG 1 & ETG 2 & ETG 3 & ETG 4 \\
\hline G & -.09 & -.02 & -.02 & -.04 & -.07 & .07 & .02 & .04 & .00 \\
\hline LWG & -.11 & -.01 & -.01 & -.15 & -.06 & -.05 & -.02 & -.02 & -.05 \\
\hline & ETG 5 & ETG 6 & ETG 7 & ETG 8 & ETG 9 & ETG 10 & ETG 11 & ETG 12 & ETG 13 \\
\hline G & -.16 & -.06 & .02 & .00 & -.03 & -.06 & -.05 & -.06 & -.09 \\
\hline LWG & -.23 & -.08 & -.02 & .13 & -.01 & -.13 & -.05 & -.07 & -.14 \\
\hline & ETG 14 & ETG 15 & ETG 16 & ETG 17 & G & LWG & & & \\
\hline G & -.12 & -.03 & -.05 & -.08 & 1.00 & & & & \\
\hline LWG & -.15 & -.05 & -.13 & -.19 & .84 & 1.00 & & & \\
\hline
\end{tabular}

Source: Own research

The abbreviations in Table 5 indicate the following: G stands for Grading, LWG means Laboratory Work Grading, T is Task, ETG stands for Experiment Task Grading. Since, the module of the minimum significant correlation coefficient (error level .01) is .13 (data from Sukhodolskyi, 1972) for this sample, we can state that there is an inverse correlation between the time spent on performing almost all tasks and the student's estimation. Thus, students who complete tasks faster and, therefore, have some cognitive skills seem to get better grades. This may implicate that there is a direct correlation between the average grading for laboratory work and control works. That is, students with higher grades for laboratory works have correspondingly higher grades for control works. This confirms the link between experimental skills and general knowledge of students.

At the same time, the analysis of the results of the students' experimental task completion shows the dynamics of reducing the students' time spent on performing a particular operation, action or logical step during the school year.

\section{CONCLUSIONS}

A learning model, based on the combination of the activity of a teacher and a student as well as forming the content of the student's activity, is suggested. The 'parallel' model of the lesson is related to the changes in the teaching material delivery and the structure of the lesson itself. Even though the model 
is intended to be used during individual and group forms of learning, it is also applicable to other learning forms. Our findings demonstrate that the developed model allows the involvement of all students in the active cognitive activity and is related to a constructivist discourse. The school physics experiment system is used as the main didactic tool, and the study of theoretical material does not necessarily require a separate time frame for passive perception. The model is based on the didactic formula and the corresponding lesson scheme, designed on the active interpretation of the study time parameter.

The present findings confirm that the designed 'parallel' model enables to increase the time for practical students' research work at physics lessons, to use time effectively in the classroom, and to improve the level of students' knowledge, skills and abilities. Continuous performance of experiments during the lessons fosters students' emotions, disciplines them, and helps to focus their attention on the learning activities. It should be noted that when applying this technology, the teacher is required to be patient and understand the peculiarities of the age group (13-14 years old). Students are emotional, like to manipulate different subjects, react boisterously to various results. However, the systematic performance of the experiments motivates students and encourages them to be active.

Our results provide evidence that students' thinking ability is activated, their interpretation of physics phenomena becomes interesting and original. Experimental tasks are also introduced to create problematic situations, which stimulate students to learn new material and provoke interest in learning. Along with experimental activity, students develop abilities to perceive the theory through practical action. This creates the prerequisites for creative activity. The 'parallel' model enables the use of individual and group forms of learning following the principle of individualization and differentiation of learning. The differentiation of other educational components, such as learning forms and methods, must be provided by taking into account the peculiarities of the student's psychic processes (sensation, perception, understanding, memory, thinking) and the requirements for studying the subject. The adherence to the principle of learning differentiation and individualization requires some structuring and differentiation of the content of the educational material and the change of approaches to teaching.

This allows the conclusion that pedagogical technologies for different disciplines can be applied on the grounds of the developed model, which is beneficial for both the novice teacher and the teacher with extensive pedagogical experience.

\section{REFERENCES}

[1] bmbwf.gv.at. (2007). Initiative "25+" : Individualisierung des Unterrichts Persönlichkeit und Lernvoraussetzungen der einzelnen Schülerinnen und Schüler in den Mittelpunkt stellen. [Initiative "25+": Individualisation of teaching: focus on the personality and learning requirements of the individual pupils]. Retrieved from: https://www.bmbwf.gv.at/Themen/schule/schulrecht/ rs/1997-2017/2007_09.html 
[2] Bray, B. \& McClaskey, K. (n.d.). Personalization vs Differentiation vs Individualization Report (PDI) v3. Retrieved from: https://www.slideshare.net/bbray/ personalization-vs-differentiation-vs-individualization.

[3] dreambox.com. (2020). Individualized Learning. Retrieved from: https://www.dreambox. com/individualized-learning.

[4] Honcharuk, P. А. (1985). Психология обучения [Psychology of teaching]. Куіv: Вища школа.

[5] Horonovska, V. T., \& Samsonova, H. V. (1985). Уроки фізики 86 класі [Physics lessons in the $6^{\text {th }}$ grade]. Kyiv: Рад.школа.

[6] Karpeta-Peć, B. (2017). Indywidualizacja nauczania i uczenia się - otwarte formy pracy $\mathrm{w}$ gimnazjum oraz w kształceniu akademickim (action research) [Individualization of teaching and learning processes - open forms of work in the gymnasiums and academic setting]. The Central European Journal of Social Sciences and Humanities (CEJSH), 49(1), 95 - 114.

[7] Karpińska, A. (2016). Indywidualizacja jako zasada i wartość w procesie kształcenia [Individualization as a principle and value in the learning process] (pp. 428-434). [In:] K. Chałas, \& A. Maj (Eds.). Encyklopedia aksjologii pedagogicznej [Encyclopedia of Pedagogical Axiology]. Radom: Polskie Wydawnictwo Encyklopedyczne.

[8] Klus-Stańska, D. (2000). Konstruowanie wiedzy w szkole [Constructing knowledge in school]. Olsztyn: Wydawnictwo UWM.

[9] Poveshchenko, H. P. (2014) Фрагменти суспільної самоорганізації [Fragments of social self-organization]. Kуiv: Спринт - Сервіс.

[10] Rotenberg, V. O., \& Bondarenko, S. М. (1989). Мозг, обучение, здоровье [Brain, Training, Health]. Moscow: Просвещение.

[11] Sadovyi, M. I., Vovkotrub, V. P., \& Tryfonova, O. M. (2013). Вибрані питання загальної методики навчання фрізики: навчальний посібник [Selected issues of methodology of physics teaching]. Kirovohrad: Авангард.

[12] Schmidt, S. J. (2010a). Rzeczywistość obserwatora. [The reality of the observer] (pp. 243 - 261). [In:] B. Balicki, D. Lewiński, B. Ryż, \& E. Szczerbuk (Eds.). Radykalny konstruktywizm. Antologia. [Radical constructivism. Anthology] Wrocław: GAJT.

[13] Schmidt, S. J. (2010b). Konstruktywizm w badaniach mediów: koncepcje, krytyka, konsekwencje [Constructivism in media studies: Concepts, criticism, implications] (pp. 243 - 261). [In:] B. Balicki, D. Lewiński, B. Ryż, \& E. Szczerbuk (Eds.). Radykalny konstruktywizm. Antologia. [Radical constructivism. Anthology]. Wrocław: GAJT.

[14] Shvay, R. I. (1999). Листок контролю виконання завдань - форма оцінювання знань та діагностика процесу індивідуального навчання (шкільний досвід) [Answer assessment sheet - the form of tasks grading and diagnostics of individual learning process (school experience)]. Materials of Ukrainian Scientific and Methodical Conference 'Relevant problems of physics teaching and learning in higher education establishments', 1. 169 - 170.

[15] Shvay, R. I. (2002). Фізика в дослідах. Зошит для лабораторних та практичних робіт. 7 клас [Physics in experiments. Workbook for laboratory works and practical tasks]. Ternopil: Навчальна книга - Богдан.

[16] Shvay, R. I., \& Hirnyy, O. I. (1999). Фізика 7. Робочий зошит [Physics 7. Woorkbook]. Lviv: ВНТЛ.

[17] Shvay, R., I., \& Hirnyy, O. I. (2000). Фізика 8. Робочий зошит [Physics 8. Woorkbook]. Lviv: ВНТЛ.

[18] Shvay, R. I., \& Hirnyy, O. I. (2003а). Фізика. Навчальний комплекс "Три в одному". 7 клас: Робочий зошит [Physics. Learning complex "Three in one". $7^{\text {th }}$ grade]. Kharkiv: ВКФ "Гриф".

[19] Shvay, R. I., \& Hirnyy, O. I. (2003b). Фізика. Навчальний комплекс "Три в одному". 8 клас: Робочий зошит. [Physics. Learning complex “Three in one". $8^{\text {th }}$ grade]. Kharkiv: Харків: ВКФ “Гриф".

[20] Sukhodolskyi, H. V. (1972) Основи математичної статистики для психологів. [Basics of mathematical statistics for psychologists]. Lviv: ЛДУ.

[21] Szwaj, R. (2016). Implementacja metod psychologii kreatywności do dydaktyki fizyki. [Implementation of psychology methods into physics didactics] (pp. 70 - 87). [In:] H. Rarot (Ed.), Humanistics and Science. Lublin: Politechnika Lubelska. 